\title{
Magnetic, geochemical and pedological characterisation of soil profiles from different environments and geological backgrounds near Coimbra, Portugal
}

\author{
A.M. Lourenço ${ }^{\text {a, } *}$, E. Sequeira $^{\text {b }}$, H. Sant'Ovaia ${ }^{c}$, C.R. Gomes ${ }^{\text {a }}$ \\ a CGUC, Department of Earth Sciences, Faculty of Sciences and Technology, University of Coimbra, Largo Marquês de Pombal, 3000-272 Coimbra, Portugal

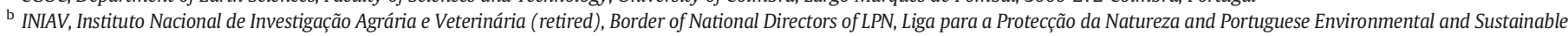 \\ Development Advisory Council, Portugal \\ c Department of Geosciences, Environment and Spatial Planning, Geology Centre from University of Porto, Faculty of Sciences, Rua do Campo Alegre, $4169-007$ Porto, Portugal
}

\section{A R T I C L E I N F O}

\section{Article history:}

Received 10 December 2012

Received in revised form 18 July 2013

Accepted 28 July 2013

Available online 20 September 2013

\section{Keywords:}

Soil profiles

Magnetic properties

Pedological parameters

Heavy metals

Portugal

\begin{abstract}
A B S T R A C T
This study presents an application of environmental magnetism techniques for the characterisation of the soils near Coimbra (central Portugal). Magnetic measurements, scanning electron microscopy and geochemical studies were carried out on samples collected in 6 soil profiles in order to find possible relationships and to interpret environmental implications. Magnetic susceptibility, saturation isothermal remanent magnetisation and isothermal remanent magnetisation at the backfield of $100 \mathrm{mT}$ and $300 \mathrm{mT}$ were measured. HardIRM \%, SIRM/ $\mathrm{x}$ and $S$-ratios were also calculated. Polluted soils showed higher values of magnetic parameters in the superficial soil horizons closer to the roads, plants and urban areas. The lowest values were observed in the deeper horizons of the soil and in the areas least disturbed by human activity. The magnetic results also suggested that the magnetic signal of these soils is mainly influenced by ferrimagnetic magnetite-like minerals and with only a minor contribution from antiferromagnetic carriers (such as hematite minerals). In unpolluted soils, lithogenic contribution is reflected by the enhancement of magnetic susceptibility near parental rock material. Scanning electron microscope images of the topsoil samples revealed the presence of magnetic spherules typical of vehicular exhaust and combustion processes. This evidence suggests that the atmospheric deposition of fly ash is the main reason for the enhancement of the magnetic signal in the topsoil. Chemical analyses showed that the concentration of various heavy metals was higher than the mean background values for Portuguese soils, and higher in superficial soils. Heavy metals showed significant positive correlation with magnetic properties. The conclusions highlight the importance of using environmental magnetism methods and techniques in the evaluation process of soil evolution and pollution history throughout time.
\end{abstract}

(c) 2013 Elsevier B.V. All rights reserved.

\section{Introduction}

In the last three decades, environmental magnetism methods have been applied to soils affected by industrial and vehicle emissions, with very good results. These non-destructive and fast techniques have been successfully applied in several fields, such as environmental monitoring, paleoclimatology, pedology and archeology. Magnetic methods (e.g. the measure of magnetic susceptibility) are valuable aids in the detection and delimitation of areas affected by pollution (e.g. Lu et al., 2008; Matýsek et al., 2008; Sant' Ovaia et al., 2012; Strzyszcz and Ferdyn, 2005; Xia et al., 2011; Zhang et al., 2012). Therefore, they can be very useful when targeting and selecting sampling sites for subsequent geochemical analyses. Industrial and traffic processes, which use fossil fuel combustion, release particulate matter (fly ash)

\footnotetext{
* Corresponding author. Tel.: +351239860 500.

E-mail addresses: ana.lourenco@dct.uc.pt (A.M. Lourenço), hsantov@fc.up.pt
} (H. Sant'Ovaia), romualdo@dct.uc.pt (C.R. Gomes). containing a significant proportion of magnetic minerals into the atmosphere (Flanders, 1999). The particles produced in this way are different from natural magnetic particles. Particles produced by pedogenic processes are smaller, predominantly in superparamagnetic (SP) $(<0.02 \mu \mathrm{m})$ to stable single domain (SSD) $(0.02-0.04 \mu \mathrm{m})$ (Dearing, 1999; Maher, 1998). Magnetic particles produced by industrial processes have a diameter of $>2 \mu \mathrm{m}$ (Flanders, 1994; Hay et al., 1997) and those from vehicular emissions are relatively smaller $(<2.5 \mu \mathrm{m})$ (Matzka and Maher, 1999). Generally, they are dominated by multidomain (MD) and SSD sizes (Hay et al., 1997). Due to their large surface area, such particles are good absorbers of several toxic metals (e.g. $\mathrm{Cd}, \mathrm{Cr}, \mathrm{Pb}$ and $\mathrm{Zn}$ ) (Kapička et al., 1999; Taylor et al., 1987). These particles are carried by the fly ash and their deposition causes an increase in the magnetic signal of the soil. Its concentration can be easily detected by measuring the magnetic properties of the soil surface samples (e.g. Lecoanet et al., 1999; Lourenço et al., 2012). Magnetic parameters, such as magnetic susceptibility $(x)$, saturation isothermal remanent magnetisation (SIRM) and ratios like S-ratio, SIRM/X and HardIRM \% (HARD \%), can 
reflect the concentration, the type and the grain size of magnetic particles in the soil. A link between $x$ and heavy metal contents is reported in many studies (e.g. El Baghdadi et al., 2011; Gautam et al., 2005; Heller et al., 1998; Karimi et al., 2011; Lourenço, 2003; Meena et al., 2011; Yang et al., 2011). The magnetic properties of soils proved to be suitable parameters, as they reflect the various degrees of contamination due to human activities and allow us to detect the area most affected by pollution. The measurement of magnetic properties in samples taken in soil profiles enables: 1) acquisition of information about the boundary depth between polluted soil and clean soil (Blaha et al., 2008), 2) discrimination between anthropogenic and lithogenic contributions (Fialová et al., 2006: Magiera et al., 2006), 3) discovery of the underlying parent material's influence on the magnetic signal (Hanesch and Scholger, 2005), 4) understanding of the development of pedogenic processes (Jordanova et al., 2010; Maher et al., 2002) and 5) attainment of climate reconstructions (Alekseeva et al., 2007; Maher et al., 2002). In the present study, data from 6 soil profiles, which formed on diverse parent material and in different environments (rural/urban), are analysed. The aims of the study are 1) to give a detailed characterisation of soil from selected areas by measuring their magnetic, pedological and chemical properties, 2) to study possible relationships and 3) to interpret environmental implications.

\section{Materials and methods}

\subsection{Study area}

The study area is located in central-northwest Portugal (Fig. 1). The climate type is mild Mediterranean. Mean annual precipitation is around $950 \mathrm{~mm}$ and mean annual temperature is $15^{\circ} \mathrm{C}$. Prevailing soil types in the area are Fluvisols, Podzols, Cambisols, Luvisols and Leptosols (Fig. 2), according to FAO/UNESCO classification (FAO, 2006). We selected this area because it presented unique and particular conditions. It has been occupied since the VIII century B. C. It has a hydrographic network where there was a lead mine (Zorro mine) and uranium mines (Urgeiriça and Cunha Baixa) located upstream, which are now inactive. There are many roads including a motorway (LisbonPorto motorway) and railway lines (such as Lisbon-Porto, CoimbraFigueira da Foz and Coimbra-Lousã). Moreover, during the 2nd half of the twentieth century, there were several branches of steel, baking, tanning, textile, pottery, beer, and rubber industries, as well as a cement factory which was not originally equipped with filters currently required by European legislation, even though it was the largest contributor of cadmium, chromium and nickel emissions. Nowadays, only a cement and pottery factory and a smelter are still in operation with environmental protection measures. In addition, a hospital in the area also burned hospital wastes for many years. Some urban and peri-urban

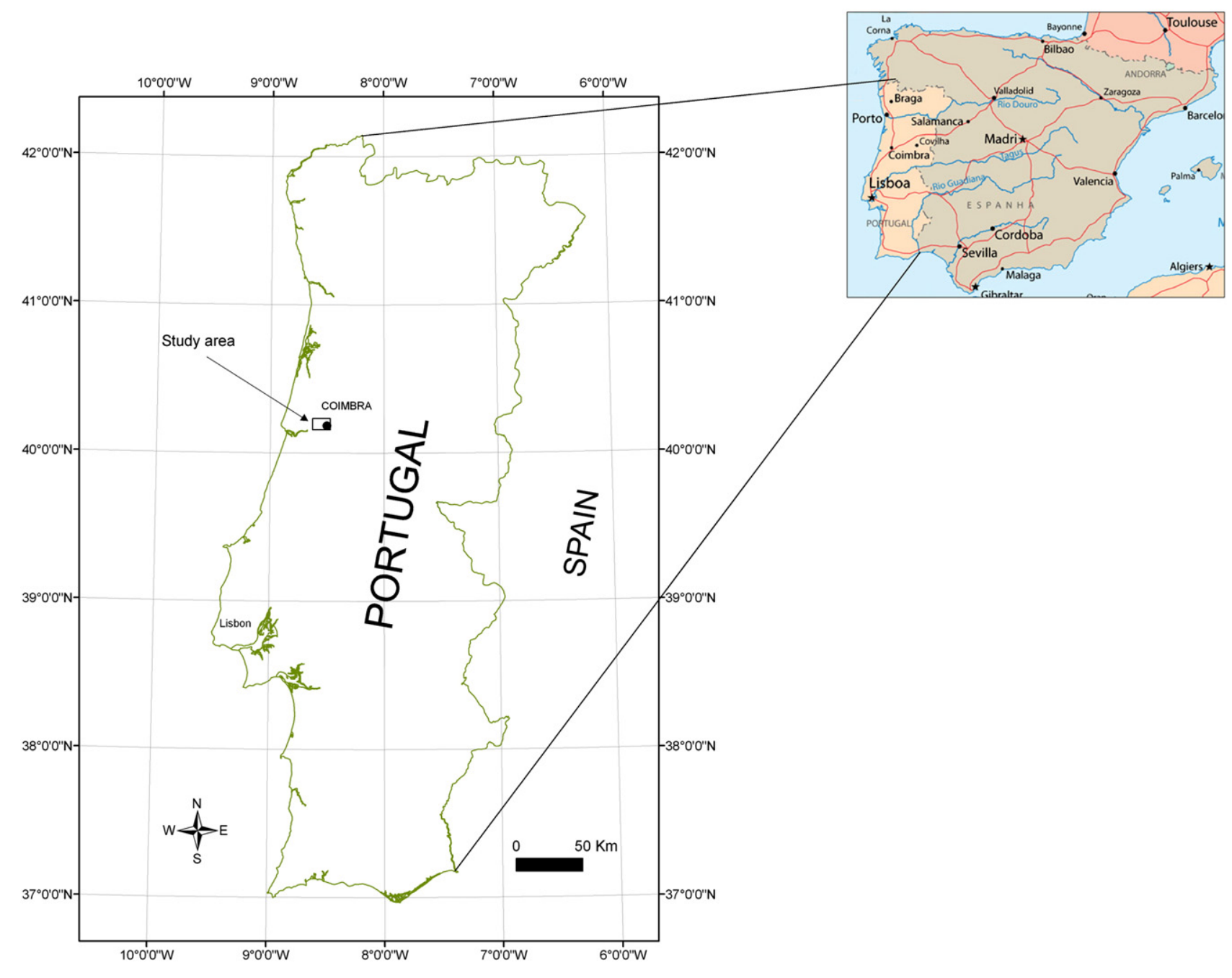

Fig. 1. Location of the study area. 


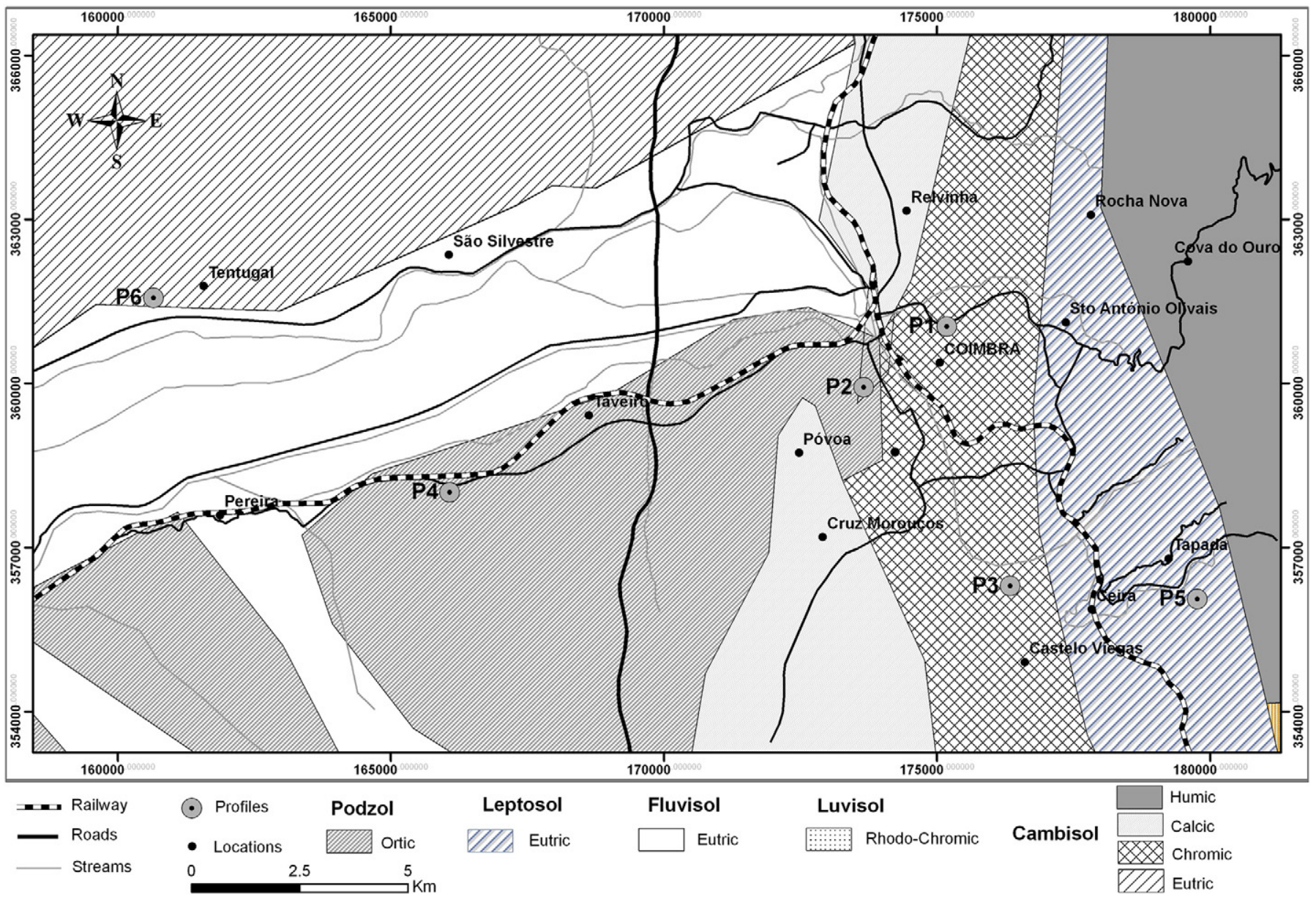

Fig. 2. Major soil types and location of soil profiles (according to Soil Map 1/1000000 from Atlas do Ambiente, 2007).

areas have irregular relief causing vehicles to emit more fumes and waste. This area also has high lead quantities as a result of the use of leaded fuel in the past. This study also includes an extensive agricultural area where agricultural machinery and chemicals, such as additives and pesticides for pest treatments, have been and are currently still being used. In the last 20 years, there was a very large expansion of urban and peri-urban areas causing some of the inhabitants to move to the city outskirts, thus contributing to an increase in road traffic and emissions.

\subsection{Soil sampling}

Profiles were collected from different locations in order to represent different types of soils and different geological backgrounds (Table 1).

Table 1

Geological background and soil type (as given in the FAO classification) of the six profiles.

\begin{tabular}{lllll}
\hline Profile & Location & $\begin{array}{l}\text { Geological } \\
\text { background }\end{array}$ & $\begin{array}{l}\text { Major soil type } \\
\text { (according to } \\
1 / 1000000 \text { map, } \\
\text { Atlas do Ambiente, } \\
2007 \text { ) }\end{array}$ & Soil type \\
& & & & \\
\hline 1 & $40^{\circ} 13^{\prime} 03^{\prime \prime} \mathrm{N} ; 8^{\circ} 25^{\prime} 35^{\prime \prime} \mathrm{W}$ & limestones & Cambisol & luvisol \\
2 & $40^{\circ} 12^{\prime} 30^{\prime \prime} \mathrm{N} ; 8^{\circ} 26^{\prime} 29^{\prime \prime} \mathrm{W}$ & sandstones & Podzol & luvisol \\
3 & $40^{\circ} 10^{\prime} 31^{\prime \prime} \mathrm{N} ; 8^{\circ} 24^{\prime} 39^{\prime \prime} \mathrm{W}$ & sandstones & Cambisol & cambisol \\
4 & $40^{\circ} 11^{\prime} 23^{\prime \prime} \mathrm{N} ; 8^{\circ} 31^{\prime} 52^{\prime \prime} \mathrm{W}$ & sandstones & Podzol & cambisol \\
5 & $40^{\circ} 10^{\prime} 22^{\prime \prime} \mathrm{N} ; 8^{\circ} 22^{\prime} 15^{\prime \prime} \mathrm{W}$ & schists & Leptosol & cambisol \\
6 & $40^{\circ} 13^{\prime} 18^{\prime \prime} \mathrm{N} ; 8^{\circ} 35^{\prime} 40^{\prime \prime} \mathrm{W}$ & sandstones & Cambisol & podzol \\
\hline
\end{tabular}

Table 2

Results of the magnetic measurements.

\begin{tabular}{|c|c|c|c|c|c|c|}
\hline Sample & $\begin{array}{l}\chi \\
\left(10^{-8} \mathrm{~m}^{3} \mathrm{~kg}^{-1}\right)\end{array}$ & $\begin{array}{l}\mathrm{IRM}_{1 \mathrm{~T}} \\
\left(10^{-3} \mathrm{Am}^{2} \mathrm{~kg}^{-1}\right)\end{array}$ & $S_{-100}$ & $S_{-300}$ & $\begin{array}{l}\operatorname{SIRM} / \chi \\
\left(\mathrm{KAm}^{-1}\right)\end{array}$ & HARD \% \\
\hline P1A & 66.89 & 2.48 & 0.79 & 0.86 & 3.70 & 6.88 \\
\hline P1B & 85.06 & 2.14 & 0.75 & 0.83 & 2.51 & 9.78 \\
\hline $\mathrm{P} 1 \mathrm{C} 1$ & 46.75 & 1.50 & 0.61 & 0.73 & 3.22 & 13.35 \\
\hline P1C2 & 21.86 & 0.78 & 0.32 & 0.51 & 3.57 & 24.41 \\
\hline P2A1 & 22.49 & 2.01 & 0.62 & 0.70 & 8.96 & 15.16 \\
\hline P2A2 & 134.93 & 20.48 & 0.88 & 0.98 & 15.18 & 1.02 \\
\hline P2B & 19.10 & 1.06 & 0.09 & 0.16 & 5.57 & 42.07 \\
\hline $\mathrm{P} 2 \mathrm{C}$ & 12.91 & 1.11 & 0.59 & 0.23 & 8.58 & 13.42 \\
\hline P3A & 35.00 & 3.15 & 0.69 & 0.81 & 8.99 & 9.34 \\
\hline Р3В & 24.04 & 2.64 & 0.42 & 0.62 & 11.00 & 19.13 \\
\hline Р3C1 & 9.30 & 1.33 & 0.04 & 0.40 & 14.32 & 29.84 \\
\hline Р3C2 & 7.50 & 1.57 & 0.12 & 0.14 & 20.94 & 43.07 \\
\hline P4A1 & 17.18 & 1.45 & 0.43 & 0.84 & 8.43 & 8.12 \\
\hline P4A2 & 33.37 & 1.93 & 0.58 & 0.90 & 5.77 & 5.04 \\
\hline P4B & 25.79 & 1.85 & 0.63 & 0.89 & 7.17 & 5.27 \\
\hline $\mathrm{P} 4 \mathrm{~B} / \mathrm{C}$ & 27.85 & 1.95 & 0.57 & 0.88 & 7.01 & 6.01 \\
\hline P4C & 9.60 & 0.89 & 0.38 & 0.81 & 9.23 & 9.41 \\
\hline P5A & 620.28 & 54.93 & 1.00 & 1.00 & 8.86 & 0.28 \\
\hline $\mathrm{P} 5 \mathrm{~A} / \mathrm{B}$ & 722.64 & 64.29 & 1.00 & 1.00 & 8.90 & 0.07 \\
\hline Р5B & 659.93 & 64.85 & 0.93 & 0.98 & 9.83 & 0.80 \\
\hline $\mathrm{P} 5 \mathrm{~B} / \mathrm{C}$ & 642.28 & 56.72 & 0.96 & 1.00 & 8.83 & 0.17 \\
\hline P5C & 363.94 & 31.96 & 0.97 & 1.00 & 8.78 & 0.24 \\
\hline P6A1 & 3.83 & 0.52 & 0.56 & 0.88 & 13.58 & 5.93 \\
\hline P6A2/B & 9.23 & 0.78 & 0.71 & 0.90 & 8.51 & 5.13 \\
\hline $\mathrm{P} 6 \mathrm{~A} 2 / \mathrm{E}$ & 16.94 & 1.36 & 0.65 & 0.90 & 8.03 & 4.99 \\
\hline P6B & 8.38 & 0.69 & 0.52 & 0.81 & 8.21 & 9.73 \\
\hline $\mathrm{P} 6 \mathrm{~B} / \mathrm{C}$ & 7.48 & 0.71 & 0.57 & 0.90 & 9.45 & 4.92 \\
\hline
\end{tabular}


The soil samples were taken from individual soil horizons and subhorizons (the material is taken from the whole depth interval of each horizon and subhorizon) with a plastic spade (carefully cleaned after each sampling). There are no major industrial plants or power plants in this area, only a smelter near profile 1 .

\subsection{Magnetic, SEM/EDS and chemical analyses}

In the laboratory, samples were dried at a maximum temperature of $40{ }^{\circ} \mathrm{C}$ to avoid any possible mineralogical changes (Maher, 1986) and then passed through a $2 \mathrm{~mm}$ sieve (we kept the $<2 \mathrm{~mm}$ fraction for analyses). Low-field magnetic susceptibility $(x)$ was measured using a KLY-4S Kappabridge magnetic susceptibility meter in the Geology
Centre of the University of Porto. Isothermal remanent magnetisation (IRM) was measured in a minispin fluxgate magnetometer (Molspin Ltd) after magnetisation in a pulse magnetiser (Molspin Ltd) in the Department of Earth Sciences, University of Coimbra. The IRM acquired in the magnetic field of one tesla $(\mathrm{T})$ was defined as saturation isothermal remanent magnetisation (SIRM). For the SEM/EDS analyses, strongly magnetic particles were extracted with a hand magnet (wrapped in plastic). Chemical analyses of $\mathrm{As}, \mathrm{Cd}, \mathrm{Co}, \mathrm{Cr}, \mathrm{Cu}, \mathrm{Ni}, \mathrm{Pb}$ and $\mathrm{Zn}$ were carried out using the ICP-MS method. Scanning electron microscope (SEM) observations were made using a JEOL JSM-5310 instrument. Compositional data for the observed grains was obtained through EDX analyses done using a Philips XL30 scanning microscope equipped with an X-ray microprobe. Conventional soil analyses

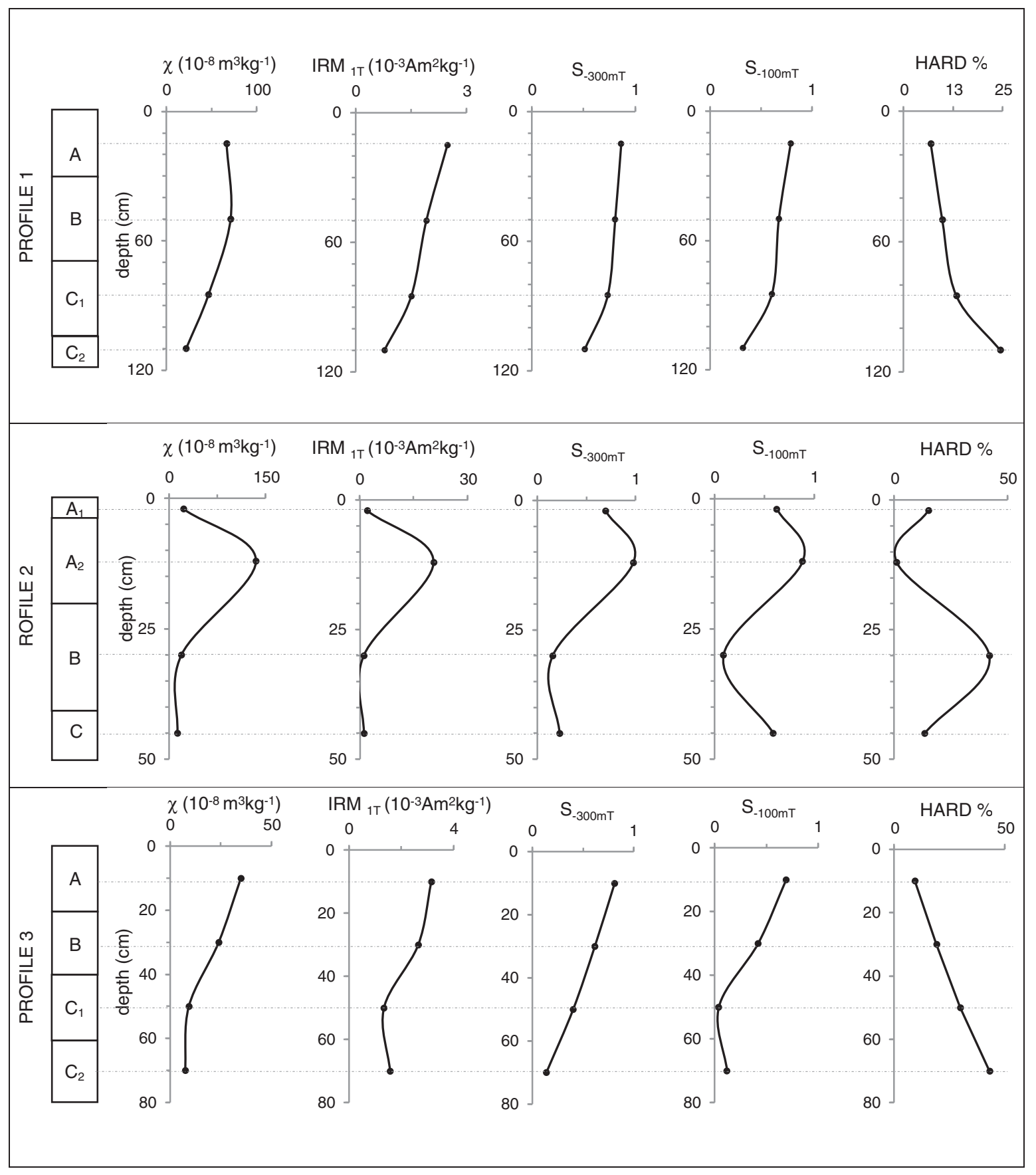

Fig. 3. Magnetic parameters for the soil profiles 1,2 and 3. 


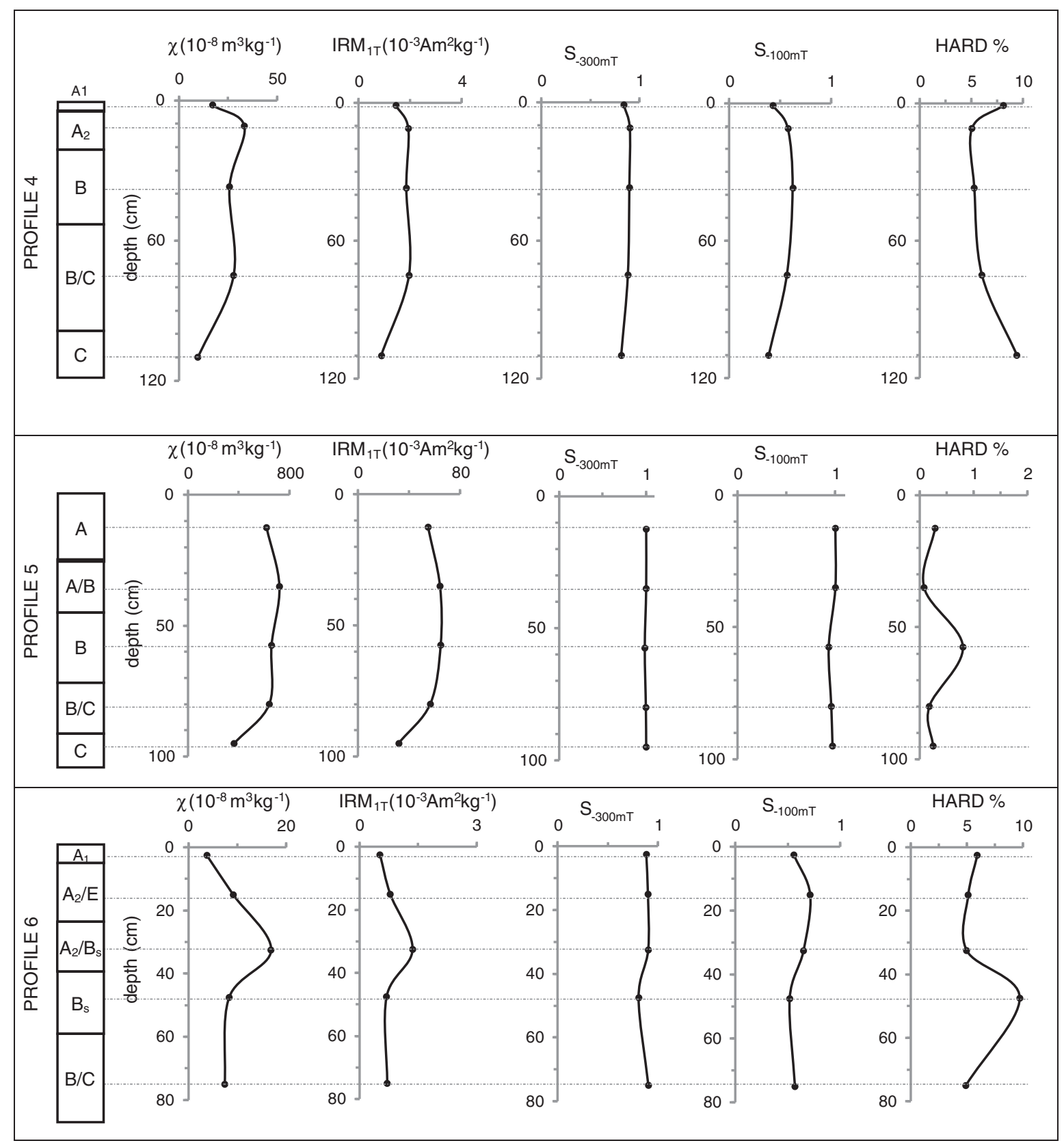

Fig. 4. Magnetic parameters for the soil profiles 4, 5 and 6.

comprise the following variables: organic matter $(\mathrm{OM}), \mathrm{pH}, \mathrm{P}_{2} \mathrm{O}_{5}$, $\mathrm{K}_{2} \mathrm{O}$ and exchangeable bases ( $\mathrm{Ca}, \mathrm{Mg}$, Na e K). Soil colour observations were obtained from air-dried samples using the Munsell soil colour chart. All the statistical data analyses were performed with SPSS (version 18.0).

\section{Results and discussion}

\subsection{Magnetic and SEM/EDS analyses}

The results of magnetic analysis are presented in Table 2. Depth changes in magnetic parameters for the 6 soil profiles studied are presented in Figs. 3 and 4. The $x$ shows a similar trend along profiles 1, 2,3 and 4, with higher values in superficial horizons. According to the published literature on soil magnetism (e.g. Maher, 1998), the most common causes for the increased values of $x$ are usually related with:
1) the synthesis of magnetite/maghemite during pedogenic processes, such as by hydrolysis and biologically induced mineralisation or by soil heating by fire; 2) the formation of greigite and 3) the deposition of fly ash which originates from industrial activity or road traffic. Since particles with typical spherical morphology were identified on the SEM images (Fig. 5) of the samples of profiles 1, 2 and 6, the high $x$ values measured on these samples are caused by anthropogenic factors related to the deposition of fly ash (urban pollution). These particles are typical of industrial emissions that involve the burning of fossil fuels (Flanders, 1994) and are reported in several studies (e.g. Gomes et al., 2008; Kim et al., 2009; Magiera et al., 2008; Maher, 2011; Spiteri et al., 2005; Yan et al., 2011; Yang et al., 2011). Atmospheric deposition of fly ash on land surfaces and vegetation cover leads to an enhanced magnetic signal (e.g. Lecoanet et al., 1999). Some particles (Fig. 5b) show pits and holes in the surface which may be caused by the dissolution of magnetic minerals by microbial activity, according to Kostka and Nealson (1995) 

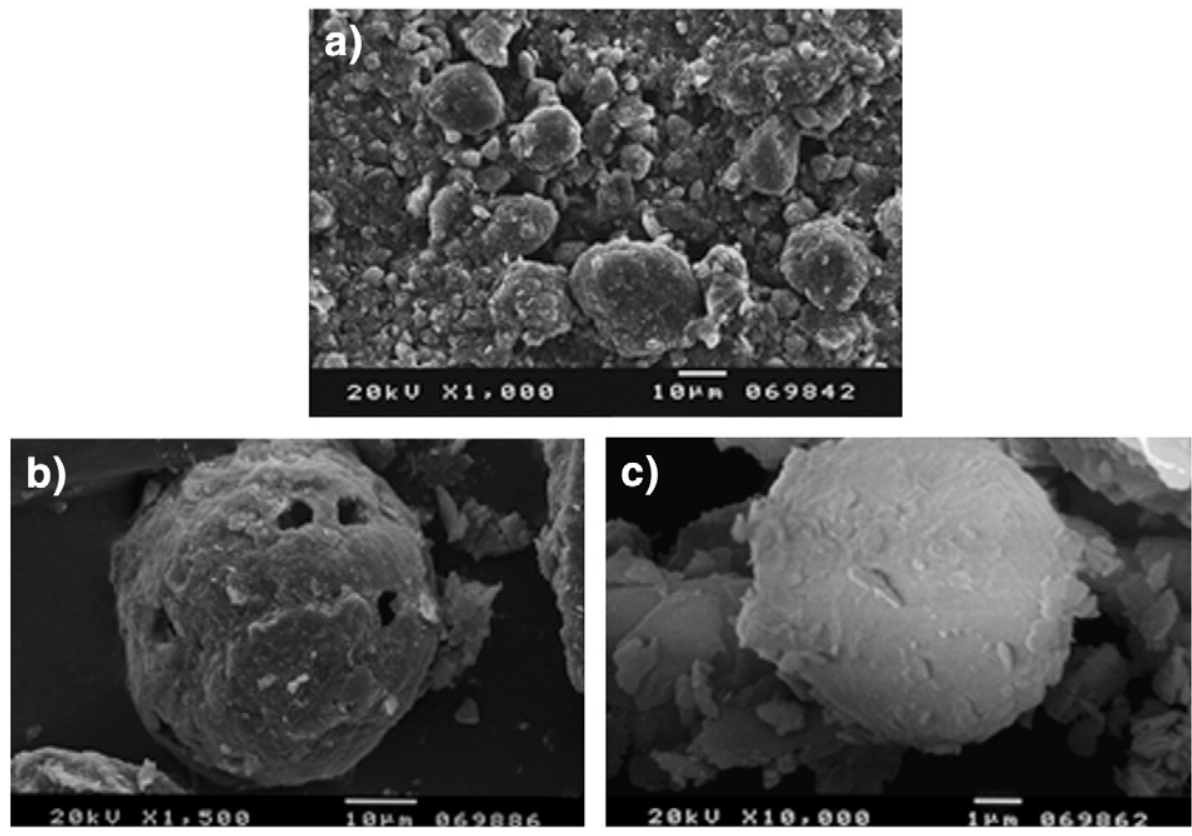

Fig. 5. Scanning electron micrograph showing spherules in horizons A of profiles a) 1, b) 2 and c) 6 .

and Yang et al. (2011). The SEM images for the superficial horizon of profiles 4 and 5 did not show this type of particles (Fig. 6). The profile 5 samples showed very high values for $x$ which may be related to the composition of the bedrock (schists). EDS analysis identified that the spherical magnetic particulates were dominantly composed of $\mathrm{Fe}$ and $\mathrm{O}$ and additional minor elements including $\mathrm{Al}, \mathrm{C}, \mathrm{K}, \mathrm{Mg}$ e Si (Fig. 7).

A few spherical particles were also observed on the superficial layer of profile 6 (Fig. 8). However, the highest $x$ values in this profile were recorded at a depth between 30 and $40 \mathrm{~cm}$. Our results are consistent with the data for podzolic soils described in Maher (1998). According to the authors, in podzolic soils the susceptibility measurements show strong magnetic depletion in the uppermost horizons (due to the iron oxide dissolution) and higher concentrations of iluviated iron oxides in spodic (iron-rich) horizon. Profile 2 shows particular $\times$ behavior with very low value for A1 subhorizon. In this profile, the A horizon has two subhorizons. The part of the A horizon having the largest accumulation of $\mathrm{OM}$ is the $\mathrm{A} 1$ horizon. The $\mathrm{A} 2$ horizon is the layer of maximum leaching or eluviation of clay and iron, so the $x$ signal is higher in this subhorizon. On the other hand, the OM on subhorizon A1 is not completely decomposed (low bacterial content) and may have a dilution effect on the magnetic signal.

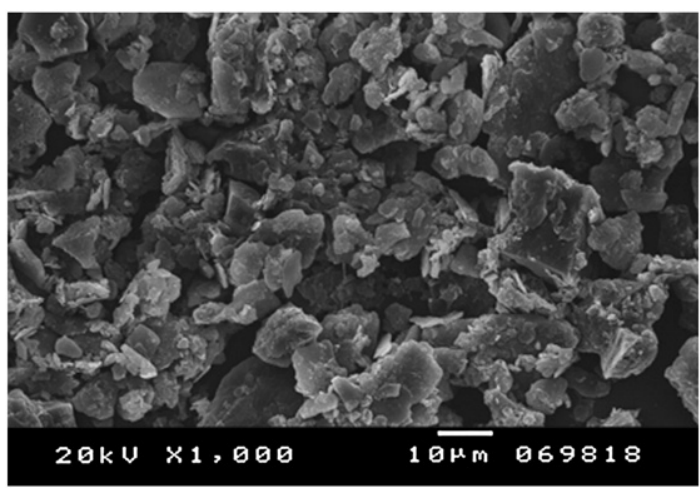

Fig. 6. Scanning electron micrograph of superficial layer of profile 5.
The IRM values have the same variation with depth as the magnetic susceptibility values along the profiles. The $S$-ratio values close to 1 indicate that magnetically soft grains control the magnetic properties of the soil samples (e.g. Chaparro et al., 2003). This situation was observed in profiles 1, 2, 4, 5 and 6 and in the uppermost layers of profile 3 . In the deeper layers of profile 3 , the values of the $S$-ratios were $<0.5$, which reflects a major antiferromagnetic contribution (Thompson and Oldfield, 1986). Red sandstones are the parent material of this profile; hematite is sometimes exclusively the dominant iron mineral in the "red-beds" and is responsible for the magnetic properties of these sediments (Collinson, 1983) and for its typical red colour. HardIRM percentage (HARD $\%=$ HIRM $/$ SIRM $\times 100$, where HIRM $=\left(\right.$ SIRM - IRM $\left.\left._{-300 ~ m T}\right) / 2\right)$, is based upon the amount of remanence remaining in a saturated sample after experiencing a backfield of $300 \mathrm{mT}$. This value is, therefore, approximately proportional to the concentration of canted antiferromagnetic minerals (e.g. haematite and goethite) within the sample (e.g. Walden and Ballantyne, 2002). Samples from profile 3 showed the highest values for this parameter, thus a dominant antiferromagnetic component is expected in these samples. The SIRM/ $x$ ratio depends on the composition and the grain-size of the magnetic particles. When the magnetic mineralogy is homogeneous, the $S I R M / x$ ratio indicates changes in the grain size of the magnetic minerals or in the contribution of paramagnetic minerals (Moreno et al., 2003). Profiles 4, 5 and 6 have SIRMs/ $x$ mean values close to $10 \mathrm{kAm}^{-1}$ and the $S_{-300}$ values $\approx 1$ (for all samples of these profiles) indicate a uniform mineralogy. According to Thompson and Oldfield (1986), the SIRMs/ $x$ values close to $10 \mathrm{kAm}^{-1}$ should be characteristic of a magnetite grain size of approximately $5 \mu \mathrm{m}$.

\subsection{Conventional soil analysis}

The results of sample characterisation for selected profiles (profiles 1, 2, 3 and 4), which were obtained through conventional soil analysis, are presented in Table 3. The OM content is low in all the samples, with the exception of horizon A1 in profile 2. Forest fires seem to be the cause of the very low values for OM observed in profile 3 because this area burned in 2005. The $\mathrm{pH}$ value ranges between 4.8 and 8.7. Profile 1 has the highest $\mathrm{pH}$ values (8.0-8.7), which reflects the influence of 

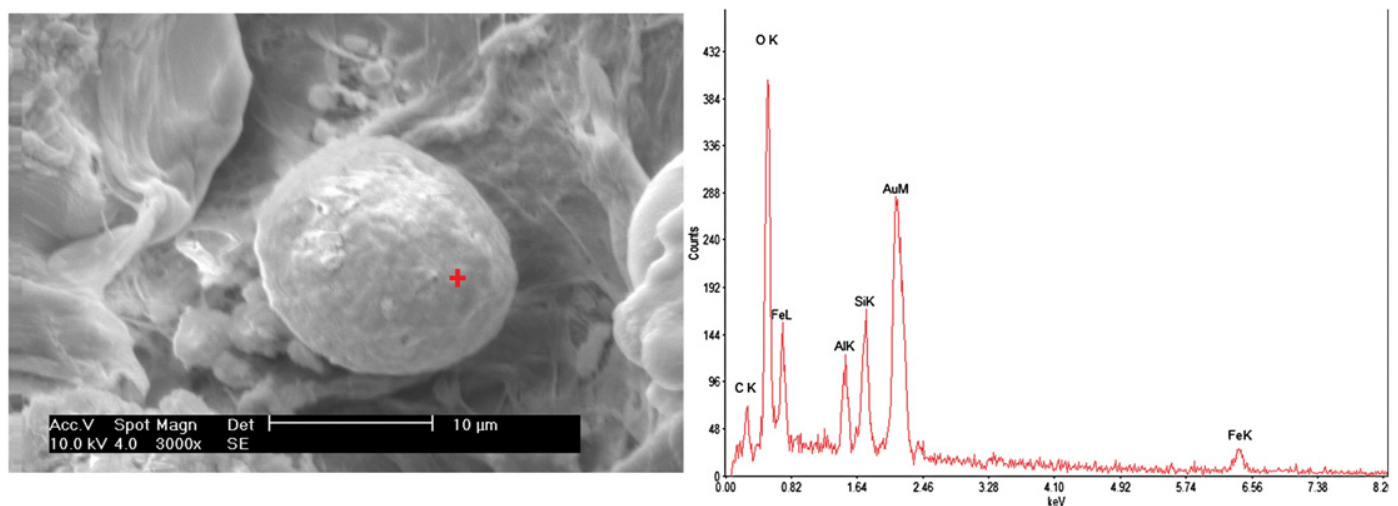

Fig. 7. Scanning electron micrographs and energy dispersive X-ray spectroscopy of magnetic extracts from selected superficial samples.

the calcareous parent rock. The $\mathrm{P}_{2} \mathrm{O}_{5}$ is very low (trace quantities) for all samples. The exchangeable bases $\mathrm{Ca}^{+}$and $\mathrm{Mg}^{+}$only have high values in profile 1.

\subsection{Correlation between magnetic and pedological parameters}

The ratios between magnetic and pedological parameters have been examined by many authors, such as Hanesch and Scholger (2005), Jordanova et al. (2010) and Maher (1998). Correlation coefficients between magnetic parameters and the other available parameters are listed in Table 4. Some groups did not yield significant results, mainly because of the small number of available samples (Hanesch and Scholger, 2005).

We expected better correlations between $\mathrm{OM}$ and the magnetic susceptibility since the presence of OM provides the necessary conditions for the reduction of iron, which favours susceptibility enhancement, but this is more likely to occur in unpolluted and natural soil. The magnetic parameter which has significant correlations with the

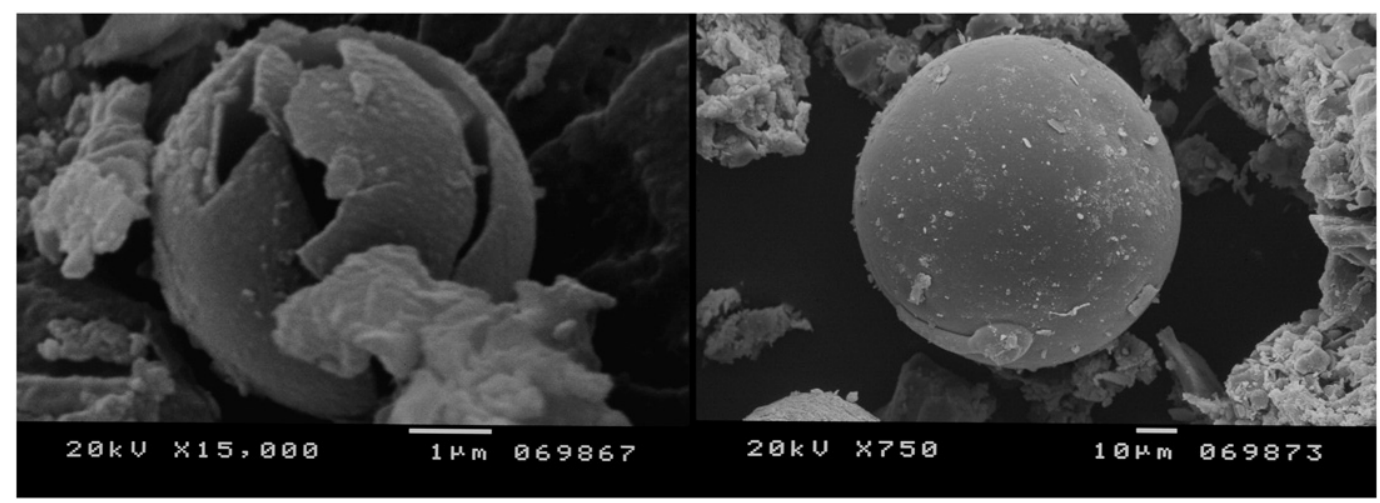

Fig. 8. Scanning electron micrograph showing spherules in the superficial layer of profile 6 .

Table 3

Results of conventional soil analysis.

\begin{tabular}{|c|c|c|c|c|c|c|c|c|c|c|}
\hline & \multirow[t]{2}{*}{ Sample } & \multirow[t]{2}{*}{ Colour } & \multirow[t]{2}{*}{$\mathrm{OM}(\%)$} & \multirow[t]{2}{*}{$\mathrm{pH}\left(\mathrm{H}_{2} \mathrm{O}\right)$} & $\mathrm{P}_{2} \mathrm{O}_{5}$ & $\mathrm{~K}_{2} \mathrm{O}$ & $\mathrm{K}^{+}$ & $\mathrm{Na}^{+}$ & $\mathrm{Ca}^{+}$ & $\mathrm{Mg}^{+}$ \\
\hline & & & & & \multicolumn{2}{|c|}{$(\mathrm{mg} / \mathrm{kg})$} & \multicolumn{4}{|c|}{ (me/100 g) } \\
\hline \multirow[t]{4}{*}{ Profile 1} & A & Reddish brown (5 YR 4/3) & 1.54 & 8.3 & Trace & $>200$ & 0.88 & 0.04 & 15.10 & 6.40 \\
\hline & $\mathrm{B}$ & Strong brown (7.5 YR) & 0.53 & 8.0 & Trace & $>200$ & 0.49 & 0.11 & 18.10 & 8.00 \\
\hline & $\mathrm{C} 1$ & Light reddish brown (2.5 YR 6/4) & 0.31 & 8.5 & Trace & 87 & 0.19 & 0.04 & 25.95 & 4.08 \\
\hline & $\mathrm{C} 2$ & Pale yellow ( 2.5 Y $8 / 4)$ & 0.12 & 8.7 & Trace & 71 & 0.14 & 0.03 & 25.52 & 3.12 \\
\hline \multirow[t]{4}{*}{ Profile 2} & $\mathrm{~A} 1$ & Reddish brown (5 YR 5/3) & 8.54 & 5.8 & Trace & 191 & 0.40 & 0.06 & 11.50 & 2.64 \\
\hline & A2 & $\operatorname{Red}(2.5$ YR $4 / 3)$ & 1.75 & 4.8 & Trace & 58 & 0.10 & 0.06 & 2.45 & 1.12 \\
\hline & B & Reddish yellow (7.5 YR 7/6) & 1.31 & 5.7 & Trace & 88 & 0.17 & 0.14 & 6.55 & 3.28 \\
\hline & C & $\operatorname{Red}(10 \mathrm{R} 4 / 8)$ & 0.62 & 5.5 & Trace & 41 & 0.07 & 0.11 & 4.35 & 2.80 \\
\hline \multirow[t]{4}{*}{ Profile 3} & A & $\operatorname{Red}(2.5$ YR $4 / 8)$ & 0.80 & 5.1 & Trace & 51 & 0.08 & 0.04 & 1.33 & 0.41 \\
\hline & $\mathrm{B}$ & Dark reddish brown (2.5 YR 2/4) & 0.39 & 5.5 & Trace & 44 & 0.07 & 0.04 & 1.49 & 0.38 \\
\hline & $\mathrm{C} 1$ & Dark reddish brown (2.5 YR 3/4) & 0.21 & 5.6 & Trace & 46 & 0.06 & 0.06 & 1.37 & 0.36 \\
\hline & $\mathrm{C} 2$ & Dark red (2.5 YR 3/6) & 0.28 & 5.8 & Trace & 54 & 0.08 & 0.17 & 2.31 & 0.64 \\
\hline \multirow[t]{5}{*}{ Profile 4} & $\mathrm{~A} 1$ & Reddish brown (2.5 YR 5/4) & 1.44 & 5.1 & Trace & 107 & 0.20 & 0.03 & 2.64 & 0.78 \\
\hline & A2 & Grayish brown (2.5 Y 5/2) & 0.85 & 5.1 & Trace & 45 & 0.07 & 0.03 & 1.85 & 0.62 \\
\hline & B & Light olive brown (2.5 Y 5/4) & 0.56 & 4.9 & Trace & 46 & 0.08 & 0.03 & 3.02 & 0.88 \\
\hline & $\mathrm{B} / \mathrm{C}$ & Brown (7.5 YR 5/2) & 0.43 & 5.0 & Trace & 22 & 0.03 & 0.08 & 0.60 & 0.26 \\
\hline & C & Pink (7.5 YR 7/4) & 0.11 & 4.8 & Trace & 19 & 0.02 & 0.02 & 0.27 & 0.14 \\
\hline
\end{tabular}


Table 4

Correlation between magnetic and pedological parameters ( $n=17)$.

\begin{tabular}{|c|c|c|c|c|c|}
\hline & & $x\left(10^{-6} \mathrm{~m}^{3} \mathrm{~kg}^{-1}\right)$ & $\operatorname{IRM}_{1 \mathrm{~T}}\left(10^{3} \mathrm{Am}^{2} \mathrm{~kg}^{-1}\right)$ & $S_{-100}$ & $S_{-300}$ \\
\hline \multirow[t]{7}{*}{ Spearman's rho } & $\mathrm{OM}$ & 0.453 & 0.406 & $0.525^{*}$ & 0.393 \\
\hline & $\mathrm{pH}$ & 0.088 & -0.264 & -0.058 & $-0.496^{*}$ \\
\hline & $\mathrm{K}_{2} \mathrm{O}$ & 0.097 & 0.004 & 0.071 & -0.138 \\
\hline & $\mathrm{K}^{+}$ & 0.455 & 0.074 & $0.469^{*}$ & 0,059 \\
\hline & $\mathrm{Na}^{+}$ & -0.069 & 0.055 & -0.045 & -0.448 \\
\hline & $\mathrm{Ca}^{+}$ & 0.319 & -0.226 & 0.286 & -0.162 \\
\hline & $\mathrm{Mg}^{+}$ & 0.427 & -0.109 & 0.419 & -0.081 \\
\hline
\end{tabular}

soil parameters is the $S_{-100}$ ratio. This ratio indicates major contribution from the true pedogenic magnetic fraction and not from the anthropogenic spherules because of the higher coercivity of these spherules, which do not permit them to contribute to IRM-100m.

The $S_{-300}$ ratio correlated with $\mathrm{pH}$ : although the correlation is significant (95\% probability), it is negative. The $x$ and IRM have low, but positive correlations with the $\mathrm{OM}$ and the exchangeable bases similar to that observed by Maher (1998) for soil samples collected in cambisols. However, despite the poor correlation, OM and $x$ have the same trend along the soil profiles with higher values in the surface horizons and decreasing at depth (Fig. 9).

\subsection{Chemical analysis}

Figs. 10, 11 and 12 show the distribution of heavy metal content in three selected profiles (profiles 1, 2 and 3). The content of $\mathrm{Cd}$ is below the limit of detection in profiles 2 and 3. In profile 1 all heavy metals analysed have high contents in A and B horizons. This profile is located inside the urban area and these values are related to anthropogenic activities/urban pollution, which is consistent with the observations of e.g. Blaha et al. (2008). The peak for $\mathrm{Zn}$ in this profile is related to the road traffic ( $\mathrm{Zn}$ is a typical pollutant by traffic emission (Reimann and Caritat, 1998): this profile is located near a road with high traffic density. The increase in heavy metal content in the surface horizons is clearly related to the increased values of $x$, thus underlining the strong association of heavy metals with the ferrimagnetic iron oxides of anthropogenic origin. Moreover, the SEM images revealed the presence of magnetic spherules (Fig. 5a). The analysis of $x$ and heavy metals variation in soil profiles allows us to establish the boundary between "clean" soil and "polluted" soil at the depth of 10-20 cm, although this limit is deeper (about $50-60 \mathrm{~cm}$ ) in profile 1.

The content of As and $\mathrm{Zn}$ in horizon A in profile 1 (As $=165 \mathrm{mg} \mathrm{kg}^{-1}$; $\mathrm{Zn}=543 \mathrm{mg} \mathrm{kg}^{-1}$ ) exceeds the AVs ("Action Values") established by Inácio et al. (2008) (Table 5). According to the authors, the "Action values $(\mathrm{AV})$, also called "intervention values", indicate concentrations above which there is an unacceptable risk to man or the environment due to soil contamination.

A reference value (RV) for a given element represents its maximum concentration in a "clean" soil and should correspond to the upper limit of the geochemical baseline: below these levels, the soil is considered multifunctional, i.e. fit for any land use, bearing in mind any limitations due to the natural composition of the soil. The $\mathrm{As}, \mathrm{Co}$ and $\mathrm{Cr}$ contents in profile 2 show an increase at depth which reveals the influence of parental material. The $\mathrm{Cu}$ peak in this profile is probably related with an old textile factory (currently demolished); $\mathrm{Cu}$ is a major component of effluents from textile industry (Belkacem et al., 2008). Profile 3 was sampled in a forest area farther away from the urban centre. The heavy metal content is quite constant along the profile, which excludes
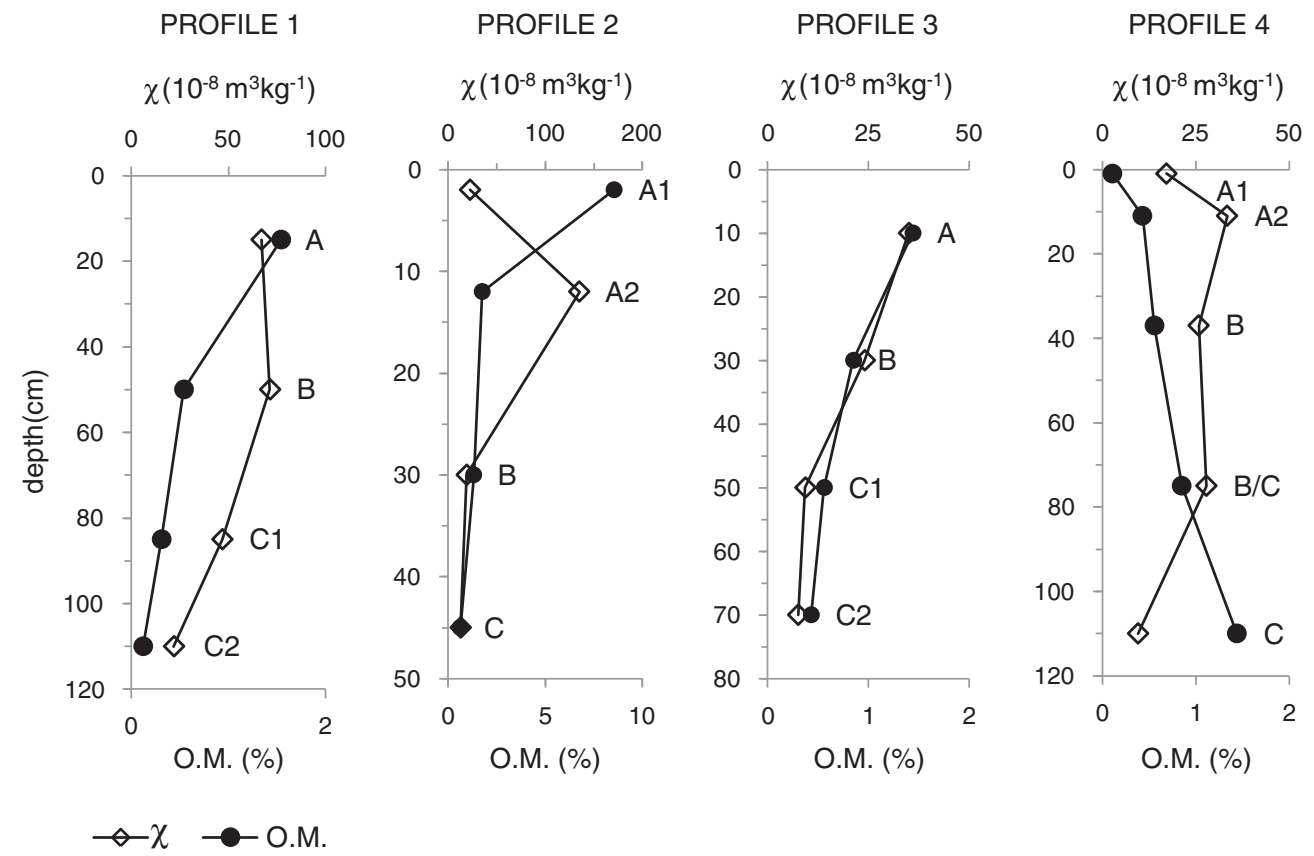

Fig. 9. Magnetic susceptibility $(x)$ and organic matter $(\mathrm{OM})$ variation for selected soil profiles. 


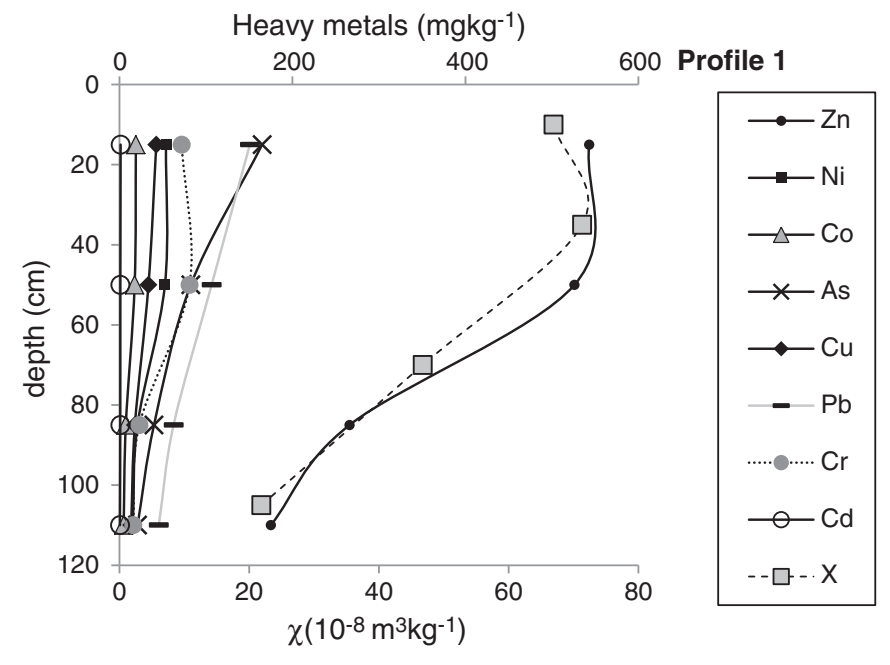

Fig. 10. Vertical distribution of $x$ and heavy metals content in profile 1.

a significant influence from urban activities. This soil can eventually serve as a magnetic and chemical background in future studies in this area. The plot in Fig. 13 shows the variation of $x$ and heavy metal content for the three profiles described above, depending on the distance to the city centre (as a reference point we chose the University of Coimbra). For each profile, the mean value of $x$ and HM contents for horizons A and B were calculated. These values decrease as a function of distance from the urban centre. These observations are consistent with those of Lu et al. (2008).

\section{Conclusions}

The $x$ shows higher values for samples taken from the surface horizons, which is related to the ferrimagnetic contribution of anthropogenic particles whose presence was confirmed by SEM observations. The highest $x$ values in podzolic soils were observed at depth. This parameter may be a useful tool in understanding the pedogenic processes and mapping soils. The $S$-ratio values indicate that magnetically soft grains

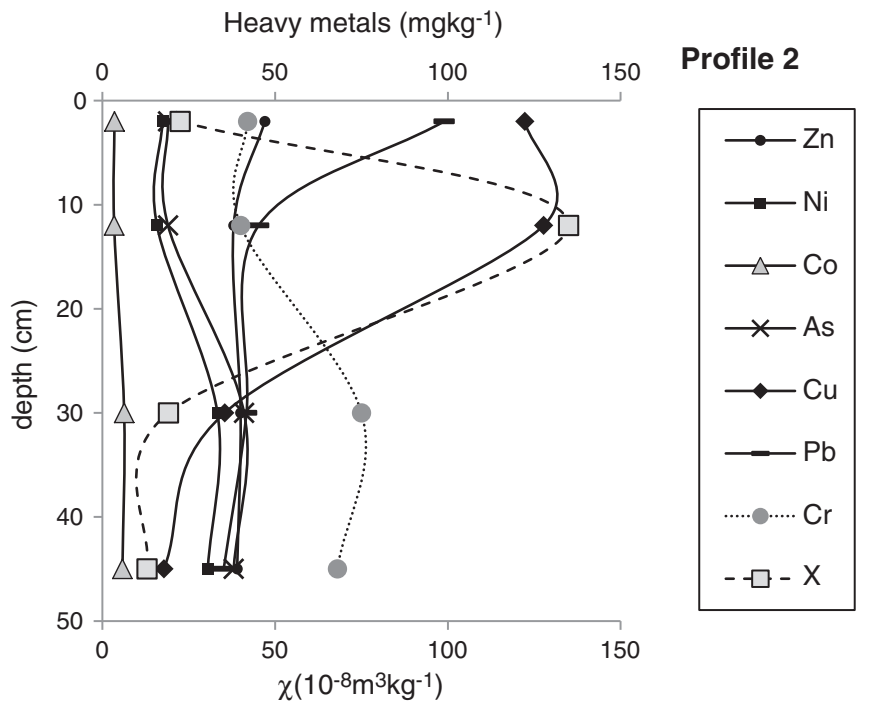

Fig. 11. Vertical distribution of $x$ and heavy metals content in profile 2 .

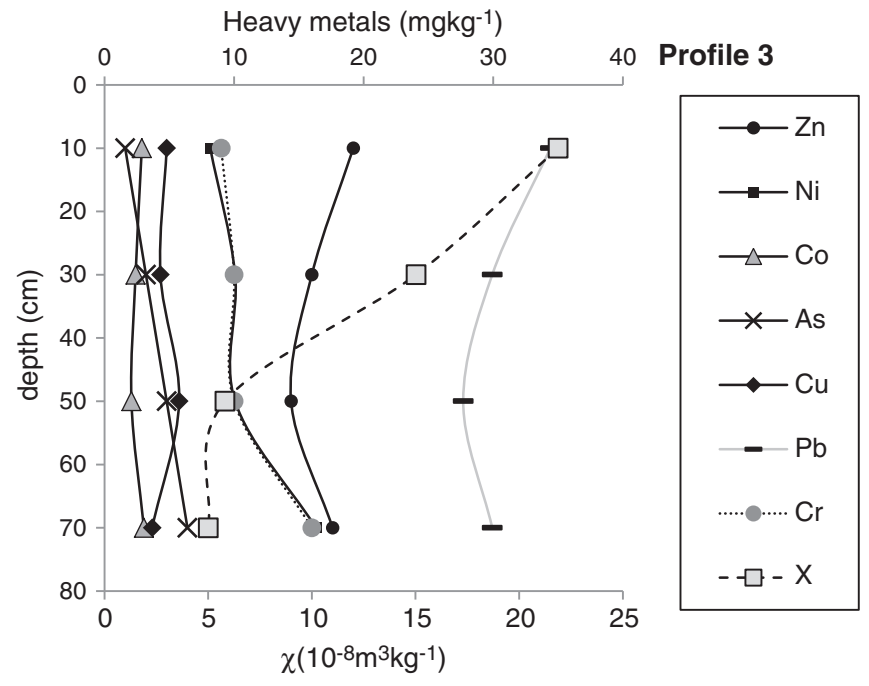

Fig. 12. Vertical distribution of $x$ and heavy metals content in profile 3 .

control the magnetic properties of the soil samples, with the exception of the deeper layers of profile 3 , where the $S$-ratio values reflect a predominantly antiferromagnetic contribution. The HARD \% values allow us to reach the same conclusion. The conventional soil analyses show that the studied soils have low OM content and the correlation coefficients between magnetic parameters and the pedological parameters did not yield significant results. Chemical analyses show that the concentration of various heavy metals was higher than the mean background values for Portuguese soils and that the highest values are from superficial soils. Heavy metal content decreases as a function of distance from the urban centre and shows the variation of magnetic parameters. Our study showed that: 1) a combination of magnetic, geochemical and pedological analyses is an effective method to study and characterise soils with different geological substrates, geographic distribution with relation to principal pollution sources and different distances measured from the urban center of Coimbra; 2) the conclusions highlight the importance of using environmental magnetism methods and techniques in the evaluation process of soil evolution and pollution history throughout time at surface and at depth.

\section{Acknowledgements}

This study was supported by the Portuguese Government through the Foundation for Science and Technology - FCT, within the PEst-OE/ CTE/UI0611/2012 Project of the Centre for Geophysics of the University of Coimbra.

Table 5

Proposed standards for As, $\mathrm{Co}, \mathrm{Cr}, \mathrm{Cu}, \mathrm{Ni}, \mathrm{Pb}$ and Zn, in Portuguese soils (Inácio et al., 2008).

\begin{tabular}{lll}
\hline & "Reference Values" (RV) & “Action Values" (AV) \\
\hline $\mathrm{As}$ & 22 & 55 \\
$\mathrm{Co}$ & 19 & 50 \\
$\mathrm{Cr}$ & 43 & 300 \\
$\mathrm{Cu}$ & 35 & 200 \\
$\mathrm{Ni}$ & 43 & 100 \\
$\mathrm{~Pb}$ & 34 & 500 \\
$\mathrm{Zn}$ & 85 & 500 \\
\hline
\end{tabular}

Concentrations in $\mathrm{mg} \mathrm{kg}^{-1}$. 


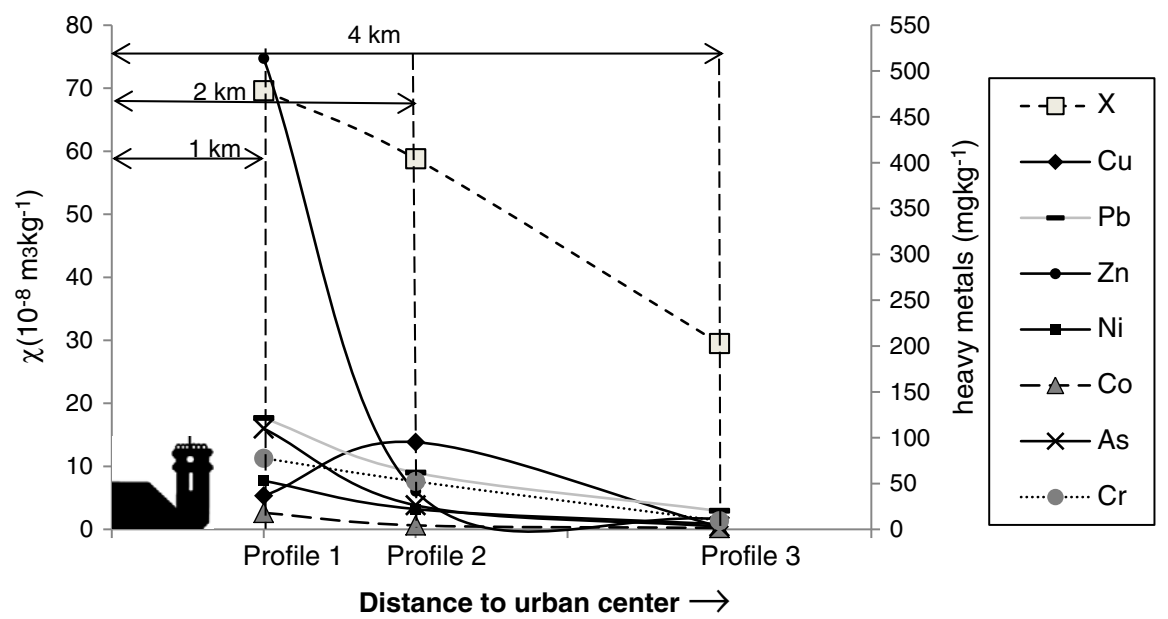

Fig. 13. Relationship between $\chi$, contents of heavy metals and distance from the centre of Coimbra.

\section{References}

Alekseeva, T., Alekseev, A., Maher, B.A. Demkin, V, 2007. Late Holocene climate reconstructions for the Russian steppe, based on mineralogical and magnetic properties of buried palaeosols. Palaeogeography Palaeoclimatology Palaeoecology 249, 103-127.

Atlas do Ambiente, 2007. Agência Portuguesa do Ambiente. http://www.iambiente.pt/atlas/.

Belkacem, M., Khodir, M., Abdelkrim, S., 2008. Treatment characteristics of textile wastewater and removal of heavy metals using the electroflotation technique. Desalination 228, 245-254

Blaha, U., Appel, E., Stanjek, H., 2008. Determination of anthropogenic boundary depth in industrially polluted soil and semi-quantification of heavy metal loads using magnetic susceptibility. Environmental Pollution 156, 278-289.

Chaparro, M.A.E., Bidegain, J.C., Sinito, A.M., Gogorza, C.S.G., Jurado, S., 2003. Preliminary results of magnetic measurements on stream-sediments from Buenos Aires province, Argentina. Studia Geophysica et Geodaetica 47, 121-145.

Collinson, D.W., 1983. Methods in rock magnetism and palaeomagnetism. Techniques and instrumentation. Chapman and Hall 503p.

Dearing, J.A., 1999. Environmental Magnetic Susceptibility. Using the Bartington MS2 System. Chi Publishing, Kenilworth, England 52p.

El Baghdadi, M., Barakat, A., Sajieddine, M., Nadem, S., 2011. Heavy metal pollution and soil magnetic susceptibility in urban soil of Beni Mellal City (Morocco). Environmental Earth Science 66 (1), 141-155.

FAO, 2006. World reference base for soil resources. World soil resources Reports. Food and Agriculture Organisation of the United Nations, Rome.

Fialová, H., Maier, G., Petrovský, E., Kapička, A., Boyko, T., Scholger, R., M.A.G.P.R.O.X.Team, 2006. Magnetic properties of soils from sites with different geological and environmental settings. Journal of Applied Geophysics 59, 273-283.

Flanders, P.J., 1994. Collection, measurements and analysis of airborne magnetic particulates from pollution in the environment. Journal of Applied Physics 75, 5931-5936.

Flanders, P.J., 1999. Identifying fly ash at a distance from fossil fuel power stations. Environmental Science and Technology 33, 528-532.

Gautam, P., Blaha, U., Appel, E., 2005. Integration of magnetism and heavy metal chemistry of soils to quantify the environmental pollution in Kathmandu, Nepal. The Island Arc 14, 424-435.

Gomes, C.R., Dinis, A.M., Rocha, A., Gomes, E., Neves, L., 2008. Magnetic properties and size of microscopic pollutant particles in the urban area of Coimbra. INCOMAN'07-International Conference on Microscopy and Microanalysis 14 (3), 144-145.

Hanesch, M., Scholger, R., 2005. The influence of soil type on the magnetic susceptibility measured throughout soil profiles. Geophysical Journal International 161, 50-55.

Hay, K., Dearing, J., Baban, S., Loveland, P., 1997. A preliminary attempt to identify atmospherically-derived pollution particles in English topsoils from magnetic susceptibility measurements. Physics and Chemistry of the Earth 22 207-210.

Heller, F., Strzyszcz, Z., Magiera, T., 1998. Magnetic record of industrial pollution in forest soils of Upper Silesia, Poland. Journal of Geophysical Research 103, 17767-17774.

Inácio, M., Pereira, V., Pinto, M., 2008. The Soil Geochemical Atlas of Portugal: overview and applications. Journal of Geochemical Exploration 98, 22-33.

Jordanova, D., Jordanova, N., Petrov, P., Tsacheva, Ts, 2010. Soil development of Chernozem-like profiles from North Bulgaria revealed by magnetic studies. Catena 83, 158-169.

Kapička, A., Petrovský, E., Ustjak, S., Macháčková, K., 1999. Proxy mapping of fly-ash pollution of soils around a coal-burning power plant: a case study in the Czech Republic. Journal of Geochemical Exploration 66, 291-297.
Karimi, R., Ayoubi, S., Jalalian, A., Sheikh-Hosseini, A.R., Afyuni, M., 2011. Relationships between magnetic susceptibility and heavy metals in urban topsoils in the arid region of Isfahan, central Iran. Journal of Applied Geophysics 74, 1-7.

Kim, W., Doh, S., Yu, Y., 2009. Anthropogenic contribution of magnetic particulates in urban roadside dust. Atmospheric Environment 43, 3137-3144.

Kostka, J.E., Nealson, K.H., 1995. Dissolution and reduction of magnetite by bacteria. Environmental Science and Technology 10, 2535-2540.

Lecoanet, H., Lévêque, F., Seguna, S., 1999. Magnetic susceptibility in environmental applications: comparison of field probes. Physics of the Earth and Planetary Interiors 115, 191-204.

Lourenço, A.M., 2003. Parâmetros magnéticos de solos na periferia da área urbana de Coimbra. Dissert. Mest. F.C.T, Univ. Coimbra 154p.

Lourenço, A.M., Rocha, F., Gomes, C.R., 2012. Relationships between magnetic parameters, chemical composition and clay minerals of topsoils near Coimbra, central Portugal. Natural Hazards and Earth System Sciences 12, 2545-2555.

Lu, S.-G., Wang, H.Y., Bai, S.Q., 2008. Heavy metal contents and magnetic susceptibility of soils along an urban-rural gradient in rapidly growing city of eastern China. Environmental Monitoring and Assessment 155, 91-101.

Magiera, T., Strzyszcz, Z., Kapička, A., Petrovský, E., M.A.G.P.R.O.X. Team, 2006. Discrimination of lithogenic and anthropogenic influence on topsoil magnetic susceptibility in Central Europe. Geoderma 130, 299-311.

Magiera, T., Kapička, A., Petrovský, E., Strzyszcz, Z., Fialová, H., Rachwał, M., 2008. Magnetic anomalies of forest soils in the Upper Silesia-Northern Moravia region. Environmental Pollution 156, 618-627.

Maher, B.A., 1986. Characterisation of soils by mineral magnetic measurements. Physics of the Earth and Planetary Interiors 42, 76-92.

Maher, B.A., 1998. Magnetic properties of modern soils and Quaternary loessic paleosols: paleoclimatic implications. Palaeogeography Palaeoclimatology Palaeoecology 137, 25-54.

Maher, B.A., 2011. The magnetic properties of Quaternary aeolian dusts and sediments, and their palaeoclimatic significance. Aeolian Research 3 (2), 87-144.

Maher, B.A., Alekseev, A., Alekseeva, T., 2002. Variation of soil magnetism across the Russian steppe: its significance for use of soil magnetism as a palaeorainfall proxy. Quaternary Science Reviews 21, 1571-1576.

Matýsek, D., Raclavská, H., Raclavský, K., 2008. Correlation between magnetic susceptibility and heavy metal concentrations in forest soils of the Eastern Czech Republic. Journal of Environmental and Engineering Geophysics 13, 13-26.

Matzka, J., Maher, B.A., 1999. Magnetic biomonitoring of roadside tree leaves: identification of spatial and temporal variations in vehicle-derived particulates. Atmospheric Environment 33, 4565-4569.

Meena, N.K., Maiti, S., Shrivastava, A., 2011. Discrimination between anthropogenic (pollution) and lithogenic magnetic fraction in urban soils (Delhi, India) using environmental magnetism. Journal of Applied Geophysics 73, 121-129.

Moreno, E., Sagnotti, L., Dinarès-Turell, J., Winkler, A., Cascella, A., 2003. Biomonitoring of traffic air pollution in Rome using magnetic properties of tree leaves. Atmospheric Environment 37, 2967-2977.

Reimann, C., Caritat, P., 1998. Chemical Elements in the Environment. Springer-Verlag 398p.

Sant' Ovaia, H., Lacerda, M.J., Gomes, C.R., 2012. Particle pollution - an environmental magnetism study using biocollectors located in northern Portugal. Atmospheric Environment 61, 340-349.

Spiteri, C., Kalinski, V., Rösler, W., Hoffmann, V., Appel, E., Magprox Team, 2005. Magnetic screening of a pollution hotspot in the Lausitz area, Eastern Germany: correlation analysis between magnetic proxies and heavy metal contamination in soils. Environmental Geology 49, 1-9.

Strzyszcz, Z., Ferdyn, M., 2005. Magnetic susceptibility and heavy metal content of soil around the coking plants in Silesia. Mitteilungen Deutsche Boden Gesellschaft 107, 557-558. 
Taylor, R.M., Maher, B., Self, P.G., 1987. Magnetite in soils: I. The synthesis of singledomain and superparamagnetic magnetite. Clay Minerals 22, 411-422.

Thompson, R., Oldfield, F., 1986. Environmental Magnetism. George Allen and Unwin, London (140 pp.).

Walden, J., Ballantyne, C.K., 2002. Use of environmental magnetic measurements to validate the vertical extent of ice masses at the Last Glacial Maximum. Journal of Quaternary Science 17, 193-200.

Xia, D.S., Yu, Y., Tian, S.L., Wang, B., Wang, L., 2011. Use of environmental magnetic techniques to monitor urban pollution origins in Lanzhou, Northwest China. Environmental Earth Science 64, 1943-1949.
Yan, H.T., Hu, S.Y., Blaha, U., Rösler, W., Duan, X.M., Appel, E., 2011. Paddy soil - a suitable target for monitoring heavy metal pollution by magnetic proxies. Journal of Applied Geophysics 75, 211-219.

Yang, T., Liu, Q., Zeng, Q., Chan, L., 2011. Relationship between magnetic properties and heavy metals of urban soils with different soil types and environmental settings: implications for magnetic mapping. Environmental Earth Science 1-12. http://dx.doi.org/10.1007/s12665-011-1248-9.

Zhang, C., Qiao, Q.. Appel, E., Huang, B., 2012. Discriminating sources of anthropogenic heavy metals in urban street dusts using magnetic and chemical methods. Journal of Geochemical Exploration 119-120, 60-75. 